\title{
Article \\ Molecular Detection of Cryptosporidium cuniculus in Rabbits (Oryctolagus cuniculus) from Tenerife, Canary Islands, Spain
}

\author{
Edgar Baz-González ${ }^{1,2} \mathbb{D}$, Natalia Martín-Carrillo ${ }^{1,2}$, Katherine García-Livia $^{1,2}$ and Pilar Foronda ${ }^{1,2, *(\mathbb{C})}$ \\ 1 Department Obstetricia y Ginecología, Pediatría, Medicina Preventiva y Salud Pública, Toxicología, \\ Medicina Legal y Forense y Parasitología, Universidad de La Laguna, 38200 San Cristóbal de La Laguna, \\ Tenerife, Canary Islands, Spain; alu0100814583@ull.edu.es (E.B.-G.); \\ nataliamartincarrillo@gmail.com (N.M.-C.); katheg116@gmail.com (K.G.-L.) \\ 2 Instituto Universitario de Enfermedades Tropicales y Salud Pública de Canarias, Universidad de La Laguna, \\ 38200 San Cristóbal de La Laguna, Tenerife, Canary Islands, Spain \\ * Correspondence: pforonda@ull.edu.es
}

check for updates

Citation: Baz-González, E.;

Martín-Carrillo, N.; García-Livia, K.; Foronda, P. Molecular Detection of Cryptosporidium cuniculus in Rabbits (Oryctolagus cuniculus) from Tenerife, Canary Islands, Spain. Vet. Sci. 2022, 9, 91. https://doi.org/10.3390/ vetsci9020091

Academic Editors: Fernando Izquierdo and Stephen K. Wikel

Received: 13 January 2022

Accepted: 16 February 2022

Published: 18 February 2022

Publisher's Note: MDPI stays neutral with regard to jurisdictional claims in published maps and institutional affiliations.

Copyright: (C) 2022 by the authors. Licensee MDPI, Basel, Switzerland. This article is an open access article distributed under the terms and conditions of the Creative Commons Attribution (CC BY) license (https:// creativecommons.org/licenses/by/ $4.0 /)$.

\begin{abstract}
Cryptosporidium cuniculus is a zoonotic parasite responsible for cryptosporidiosis cases and outbreaks in both humans and rabbits. Since there are no molecular Cryptosporidium spp. infection data in rabbits (Oryctolagus cuniculus) from Spain, our aim was to gather information about this parasite in wild European rabbits from Tenerife, Canary Islands (Spain). A total of 100 faecal samples were collected from rabbits from eight municipalities of Tenerife. Microscopic analysis showed that $4.0 \%$ of the samples presented structures compatible with Cryptosporidium oocyst. A nested polymerase chain reaction (PCR) targeting $18 S$ ribosomal RNA (rRNA) gene fragments was carried out, and sequencing confirmed the identity of C. cuniculus in one sample (1.0\%). The sample was successfully subtyped using nested PCR analysis of the $60-\mathrm{kDa}$ glycoprotein $(g p 60)$ gene as the subtype VbA26R3. This study confirms the presence of $C$. cuniculus in wild rabbits from Tenerife, providing new information on the occurrence of this zoonotic parasite. Further studies are required to better understand the epidemiology of Cryptosporidium spp. in wild rabbits in Spain and their possible public health repercussions.
\end{abstract}

Keywords: Cryptosporidium cuniculus; zoonoses; Oryctolagus cuniculus; rabbits; Canary Islands; Spain

\section{Introduction}

The Canary Islands are a Spanish archipelago composed of eight islands and five islets located in the Atlantic Ocean, near the coast of northwest Africa $\left(13^{\circ} 23^{\prime}-18^{\circ} 8^{\prime} \mathrm{W}\right.$ and $\left.27^{\circ} 37^{\prime}-29^{\circ} 24^{\prime} \mathrm{N}\right)$. The European rabbit (Oryctolagus cuniculus), an "invasive introduced" species [1] native to the Iberian Peninsula, was introduced to these islands in the 15th century [1]. Nowadays, it has been established as a species of economic and cultural interest in the islands, due to hunting activity and farming. The Canary Islands have $3.2 \%$ of the rabbit farms of Spain [2] and the wild rabbit is one of the small game hunting species in Tenerife [1]. In 2017, rabbit abundance was estimated in a mean value of 2.22 individuals/ha in Tenerife, with a standard derivation of 2.25 individuals/ha, which suggests that there is high spatial variability in the abundance of the species. In general, abundance was higher in areas of low elevation and slope [3].

The European rabbit is a well-known host of several pathogens such as helminths, viruses, and protozoa [4], including Cryptosporidium spp.

Cryptosporidium is a genus of parasitic protozoa comprising of 48 valid species and more than 100 genotypes [5] that infect a wide range of hosts, including humans, mammals, birds, reptiles, and fish [6]. The transmission of the infective stage occurs through the ingestion of sporulated oocysts via contact with an infected person/animal, ingestion of contaminated water or food, or possibly through the air [7]. Infection ranges from 
being asymptomatic to mild-severe diarrhea. The parasite has a cosmopolitan distribution, particularly in developing countries [8].

Since Cryptosporidium spp. infection was first detected in a rabbit in 1912 by Tyzzer [9], other cases in this mammal have been reported, most of them caused by Cryptosporidium cuniculus (previously known as Cryptosporidium rabbit genotype), which first identified using transmission electron microscopy in 1979 [10], and was morphologically and molecularly re-described and characterized in 2010 [11]. The notable countries of C. cuniculus infection in rabbits are the USA [10], China [12-18], the Czech Republic [19], New Zealand [20], the United Kingdom (UK) [21], Australia [22-26], Poland [27], Brazil [28], and Egypt [29]. Although C. cuniculus is the most frequent species detected in rabbits, Cryptosporidium fayeri and Cryptosporidium parvum have also been reported in this lagomorph in Australia and Nigeria, respectively [26,30].

To date, the known hosts for C. cuniculus are humans, rabbits (O. cuniculus), Eastern grey kangaroos (Macropus giganteus) [31], and more recently, alpacas (Vicugna pacos) have been studied as possible host [32]. It has also been found in wastewater treatment plants in the UK [21,33], China [34,35], Brazil, Peru [36], Spain [37], and Australia [38,39]; in rivers in China [40], Australia [41], and South Africa [42]; and sources of water in Australia [43,44].

In humans, the most common etiologic agents of cryptosporidiosis are Cryptosporidium hominis and Cryptosporidium parvum [45], while Cryptosporidium canis, Cryptosporidium cuniculus, Cryptosporidium erinacei, Cryptosporidium felis, Cryptosporidium meleagridis, Cryptosporidium tyzzeri, and Cryptosporidium ubiquitum are associated with a lower number of cases [46]. C. cuniculus has been reported as a confirmed agent of human cryptosporidiosis in (see Table 1) the UK [21,47-49], France [50-52], Nigeria [53], Australia [31], New Zealand [54-56], Canada [57], Sweden, and Greece [58]. To date, the only two cases linked to Spain are the case of a symptomatic pediatric patient from Madrid [59] and a Spanish travel-related case [58].

Table 1. Human confirmed cryptosporidiosis cases by Cryptosporidium cuniculus reported.

\begin{tabular}{|c|c|c|c|c|}
\hline Country & Subtype $(n)$ & Period & $\begin{array}{c}\text { Case/Prevalence }(\%) \\
(n-\text { Positive Cases/Total) }\end{array}$ & Reference \\
\hline UK & VaA22 (1) & 2007 & 1 case ${ }^{*}$ & {$[21,47]$} \\
\hline UK & $\begin{array}{c}\operatorname{VbA} 11(1), \operatorname{VbA} 20(1), \\
\operatorname{VbA} 22(1), \operatorname{VbA} 23(1), \\
\operatorname{VbA} 25(1), \operatorname{VbA} 26(1), \\
\operatorname{VbA} 28(1), \operatorname{VbA} 29(2), \\
\operatorname{VbA} 30(1), \operatorname{VbA} 32(1), \\
\operatorname{VbA} 33(1), \operatorname{VbA} 34(1), \\
\operatorname{VbA} 36(1), \operatorname{VbA} 37(1), \\
\text { VaA9 (1), VaA18 (1) } \\
\text { VaA19 (1), VaA21 (1) } \\
\text { VaA22 (1) }\end{array}$ & $2007-2008$ & $1.2 \%(37 / 3,030)$ & [48] \\
\hline UK & VaA18 (23) & 2008 & 23 cases (422 estimated) & {$[21,33]$} \\
\hline Nigeria & - & $2006-2007$ & $6.5 \%(5 / 77)$ & [53] \\
\hline France & - & $2006-2009$ & $0.3 \%(1 / 310)$ & [50] \\
\hline Australia & $\mathrm{VbA} 25(1)$ & 2009 & 1 case $^{*}$ & [31] \\
\hline Spain & VbA34 (1) & 2015 & 1 case $^{*}$ & [59] \\
\hline New Zealand & $\begin{array}{l}\text { VbA22 (2) } \\
\text { VbA25 (1) } \\
\text { VbA27 (1) }\end{array}$ & 2009-2015 & $0.7 \%(4 / 579)$ & [54] \\
\hline France & - & $2015-2017$ & $1 \%(1 / 87)$ & [51] \\
\hline
\end{tabular}


Table 1. Cont.

\begin{tabular}{|c|c|c|c|c|}
\hline Country & Subtype (n) & Period & $\begin{array}{c}\text { Case/Prevalence (\%) } \\
\text { ( } n^{\circ} \text { Positive Cases/Total) }\end{array}$ & Reference \\
\hline France & - & $2017-2019$ & $>1 \%$ (no data) & [52] \\
\hline New Zealand & $\begin{array}{l}\operatorname{VbA} 13(2), \operatorname{VbA} 15(1) \\
\operatorname{VbA} 17(4), \operatorname{VbA} 22(3) \\
\operatorname{VbA} 23(2), \operatorname{VbA} 24(5) \\
\operatorname{VbA} 25(8), \operatorname{VbA} 26(3) \\
\operatorname{VbA} 27(2), \operatorname{VbA} 28 \text { (3) }\end{array}$ & 2009-2019 & $1.3 \%(33 / 2,598)$ & [55] \\
\hline New Zealand & $\mathrm{Vb}$ & $2015-2021$ & $1.9 \%(28 / 1,502)$ & [56] \\
\hline Canada & VbA38 (1) & 2008-2017 & $0.8 \%(1 / 129)$ & [57] \\
\hline $\begin{array}{l}\text { Sweden } \\
\text { Spain } \\
\text { Greece }\end{array}$ & $\begin{array}{c}\text { VaA19 }(1) \\
\text { VbA20R2 (1) } \\
\text { VbA29R4 (1) } \\
\text { VbA25R3 (1) } \\
\text { VbA31R4 (1) }\end{array}$ & 2013-2014 & $1.3 \%(5 / 379)$ & [58] \\
\hline UK & - & $2018-2020$ & $2.8 \%(3 / 109)$ & [49] \\
\hline
\end{tabular}

${ }^{*}$ No prevalence data.

In the Canary Islands, several Cryptosporidium species/genotypes have been reported: in patients from Tenerife [60], Gran Canaria, Lanzarote, and La Palma [61,62]; in pigeons (Columba livia) from Gran Canaria and Tenerife [63,64]; in rodents from Tenerife, La Palma, and El Hierro [65,66]; and in hedgehogs (Atelerix algirus) [67] and wastewater from Tenerife $[68,69]$. Since there is no infection data in rabbits in the islands, the aim of the present study was to screen a wildlife population of rabbits from Tenerife for the presence of Cryptosporidium spp. with staining and molecular methods.

\section{Materials and Methods}

\subsection{Sample Collection}

A total of 100 faecal samples from rabbits donated by hunters $(n=82)$ and found dead $(n=18)$, from eight municipalities of Tenerife: Tegueste, San Cristóbal de La Laguna, El Sauzal, La Matanza de Acentejo, Arafo, La Orotava, Güímar, and Granadilla de Abona (Figure 1) were collected between 2015-2017 and placed into sterile plastic containers until reception in the laboratory, then were subsequently deposited in vials containing $2.5 \%$ aqueous $(w / v)$ potassium dichromate $\left(\mathrm{K}_{2} \mathrm{Cr}_{2} \mathrm{O}_{7}\right)$ solution. The samples were stored at $4{ }^{\circ} \mathrm{C}$ until the posterior analysis.

\subsection{Ethical Statement}

The samples used in this study were donated by hunters that hunted wild rabbits during the legal hunting season period, detailed in the numbers of the Official Bulletin of Canaries (BOC) (http:/ / www.gobiernodecanarias.org/boc/ accessed on 11 February 2022); 128 from 2015, and 125 from 2016 and 2017, respectively. Therefore, no rabbits were sacrificed for this study. No ethical approval was required. 


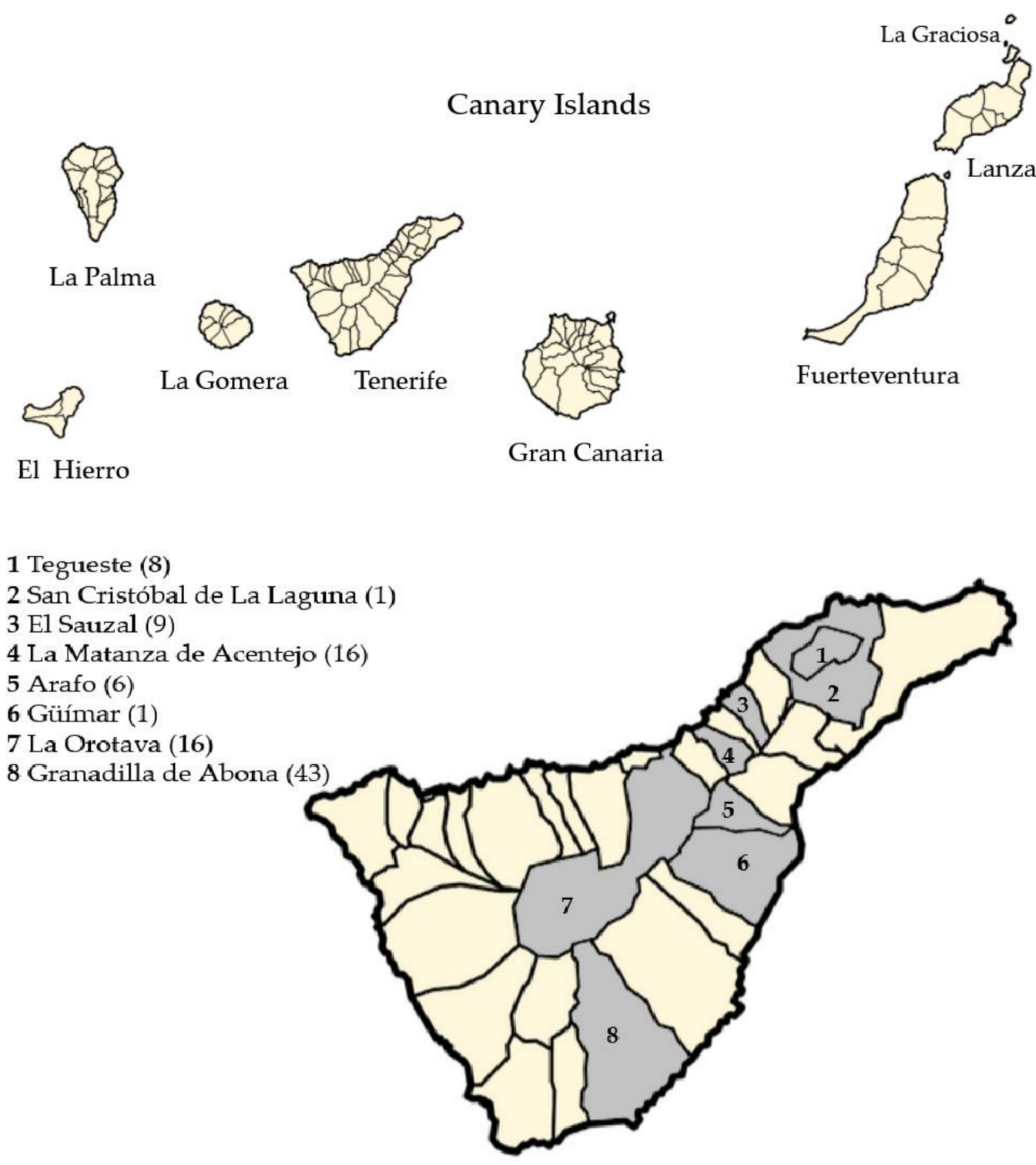

Figure 1. The sampling area. Map of the Canary archipelago and the island of Tenerife showing in grey zones the sampled municipalities. Inserted in brackets are the number of samples/municipality (The original images were taken from Wikimedia Commons (https://commons.wikimedia.org/w / index.php?title=File:Mapa_Canarias_municipios.svg\&oldid=478721455, accessed on 11 February 2022; https:/ / upload.wikimedia.org/wikipedia/commons/d/d1/Mapa_Canarias_municipios.svg, accessed on 11 February 2022; https: / / commons.wikimedia.org/wiki/File:Mapa_Canarias_munici pios.svg, accessed on 11 February 2022; https:/ / upload.wikimedia.org/wikipedia/commons/d/d 1/Mapa_Canarias_municipios.svg, accessed on 11 February 2022) in which the permission to copy, distribute, or adapt it is established. User: Júlio Reis (https:/ / commons.wikimedia.org/wiki/User: Tintazul accessed on 11 February 2022). The images were edited by the Paint 3D program).

\subsection{Staining Method}

Samples were stained using the Kinyoun TB Stain Kit K (Becton, Dickinson and Company, USA) following the manufacturer's instructions and microscopically screened for Cryptosporidium spp. oocysts. The samples with oocyst-compatible structures were identified as positive and preserved until DNA extraction and PCR analysis. 


\subsection{DNA Extraction}

An aliquot of $\sim 200 \mu \mathrm{L}$ of each sample identified as positive diluted in potassium dichromate was washed with PBS-EDTA at room temperature to remove the potassium dichromate. Then, they were transferred to centrifuge tubes containing $500 \mu \mathrm{L}$ of lysis buffer, and one freeze-thaw cycle $\left(-80{ }^{\circ} \mathrm{C}\right.$ to $\left.+100{ }^{\circ} \mathrm{C}\right)$ in boiling water was made prior the extraction procedure [70]. Total DNA was isolated with the commercial FastDNA ${ }^{\circledR}$ Spin Kit for Soil (MP Biomedicals, Solon, OH, USA) following the manufacturer's instructions, with the homogenizer FastPrep-24 ${ }^{\mathrm{TM}} 5 \mathrm{G}$ (MP Biomedicals, Solon, OH, USA) as oocyst disruptors.

\subsection{PCR Amplification}

Two Cryptosporidium spp. genes fragments were amplified by nested PCR (Table 2). The first one was performed targeting an $830 \mathrm{bp}$ nucleotide fragment of the $18 \mathrm{~S}$ ribosomal RNA (rRNA) gene, using the primers SSU-F1/SSU-R1 for the primary and SSU-F2/SSU-R2 for the secondary reactions [71]. The reaction mixture in both steps of the nested PCR contained $0.125 \mu \mathrm{L}$ of Taq DNA polymerase $(5 \mathrm{U} / \mu \mathrm{L})(\mathrm{VWR}), 1 \mu \mathrm{L}$ of each primer $(10 \mu \mathrm{M})$, $2.5 \mu \mathrm{L}$ of dNTPs mix (200 $\mu \mathrm{M})$ (Bioline, London, UK), $1 \mu \mathrm{L} \mathrm{MgCl}_{2}(25 \mathrm{mM})$ (VWR), $2.5 \mu \mathrm{L}$ $10 \times$ key buffer $\left(15 \mathrm{mM} \mathrm{Mg}^{2+}\right.$ ) (VWR), $2 \mu \mathrm{L}$ of DNA template (or $2 \mu \mathrm{L}$ of primary PCR product for the secondary PCR), and water, to a total volume of $25 \mu \mathrm{L}$.

Table 2. PCR primers and conditions used in this study for Cryptosporidium gene amplification.

\begin{tabular}{|c|c|c|c|c|}
\hline Target Gene & Primer & Primer Sequences $\left(5^{\prime}-3^{\prime}\right)$ & Expected Size (bp) & PCR Conditions 1 \\
\hline \multirow[t]{2}{*}{$18 S$ rRNA } & $\begin{array}{l}\text { 18SF1 } \\
\text { 18SR1 }\end{array}$ & $\begin{array}{c}\text { CCCATTTCCTTCGAAACAGGA } \\
\text { TTCTAGAGCTAATACATGCG }\end{array}$ & 830 & $\begin{array}{c}94^{\circ} \mathrm{C}-45 \mathrm{~s} \\
55^{\circ} \mathrm{C}-45 \mathrm{~s} \\
72^{\circ} \mathrm{C}-1 \mathrm{~min} \\
\text { For } 35 \text { cycles }\end{array}$ \\
\hline & $\begin{array}{l}\text { 18SF2 } \\
18 S R 2\end{array}$ & $\begin{array}{l}\text { AAGGAGTAAGGAACAACCTCCA } \\
\text { GGAAGGGTTGTATTATTAGATAAAG }\end{array}$ & & $\begin{array}{c}94^{\circ} \mathrm{C}-45 \mathrm{~s} \\
58^{\circ} \mathrm{C}-45 \mathrm{~s} \\
72^{\circ} \mathrm{C}-1 \mathrm{~min} \\
\text { For } 35 \text { cycles }\end{array}$ \\
\hline \multirow[t]{2}{*}{ gp60 } & $\begin{array}{l}\text { AL3531 } \\
\text { AL3535 }\end{array}$ & $\begin{array}{l}\text { ATAGTCTCCGCTGTATTC } \\
\text { GGAAGGAACGATGTATCT }\end{array}$ & $800-850$ & \multirow{2}{*}{$\begin{array}{c}94^{\circ} \mathrm{C}-45 \mathrm{~s} \\
50^{\circ} \mathrm{C}-45 \mathrm{~s} \\
72{ }^{\circ} \mathrm{C}-1 \mathrm{~min} \\
\text { For } 35 \text { cycles } \\
\text { (both steps) }\end{array}$} \\
\hline & $\begin{array}{l}\text { AL3532 } \\
\text { AL3534 }\end{array}$ & $\begin{array}{l}\text { TCCGCTGTATTCTCAGCC } \\
\text { GCAGAGGAACCAGCATC }\end{array}$ & & \\
\hline
\end{tabular}

${ }^{1}$ All nested PCR conditions were preceded by 5 min at $95^{\circ} \mathrm{C}$ and a final step of $10 \mathrm{~min}$ at $72{ }^{\circ} \mathrm{C}$.

The subtype of the positive samples was detected targeting an 800-850 bp nucleotide fragment of the 60-kDa glycoprotein ( gp60) gene, using the primers AL3531/AL3535 for the primary, and AL3532/AL3534 for the secondary PCRs [72]. The reaction mixture contained $0.125 \mu \mathrm{L}$ of Taq DNA polymerase $(5 \mathrm{U} / \mu \mathrm{L})$ (VWR), $0.5 \mu \mathrm{L}$ of each primer $(10 \mu \mathrm{M}), 2.5 \mu \mathrm{L}$ of dNTPs mix (200 $\mu \mathrm{M})$ (Bioline, London, UK), $1.5 \mu \mathrm{L} \mathrm{MgCl}_{2}(25 \mathrm{mM})(\mathrm{VWR}), 2.5 \mu \mathrm{L} 10 \times$ key buffer (15 $\mathrm{mM} \mathrm{Mg}^{2+}$ ) (VWR), $1 \mu \mathrm{L}$ of DNA template (or $1 \mu \mathrm{L}$ of primary PCR product in the secondary PCR), and water, to a total volume of $25 \mu \mathrm{L}$.

PCR reactions were performed in a XP Cycler (Bioer Technology, Hangzhou, China) thermocycler and were visualized on $1.5 \%(w / v)$ agarose gels (Fisher Bioreagents, Madrid, Spain) stained with REALSAFE Nucleic Acid Staining Solution (20,000×, REAL, Durviz S.L., Valencia, Spain).

The nested PCR products were sequenced at Macrogen Spain, with the secondary pair of primers in both senses. 


\subsection{Sequencing and Phylogenetic Analysis}

The fragments of the nucleotide sequences obtained were edited with the MEGA $X$ program [73], and subsequently aligned with other Cryptosporidium species/subtypes sequences using the ClustalW program included in MEGA X. Minor corrections, to increase the aligned sequence similarity and improve the inferences on any positional homology, were then made by hand.

A Basic Local Alignment Search Tool (BLAST) search was carried out in order to elucidate any homologies or similarities with the sequences previously published in the GenBank database.

The molecular identification of the $18 S$ rRNA and gp60 genes was achieved by phylogenetic analysis through the Neighbor-Joining distance method with the p-distance model [74] and maximum-likelihood method with a Tamura-Nei model [75], both with at least 1000 bootstrap replications in MEGA X using the sequence of Eimeria magna (HQ173833.1) as the outgroup. Nucleotide sequences obtained in this work were submitted to the GenBank database under the accession numbers OM170342 and OM249938 for 18S rRNA and gp60 genes, respectively.

\section{Results}

\subsection{Staining and Molecular Results}

In four $(4.0 \%)$ of the faecal samples screened by the Kinyoun method and light microscopy, Cryptosporidium oocyst-compatible structures were found. One sample was amplified by nested PCR with the expected size, and it was identified as C. cuniculus by sequencing.

Therefore, the occurrence of C. cuniculus in wild rabbits from Tenerife was $1.0 \%(1 / 100)$. The positive sample was located in La Orotava from a rabbit donated by hunters, with an overall occurrence of $6.25 \%(1 / 16)$ in this municipality.

\subsection{Phylogenetic Analyses}

\subsection{1. $18 S$ rRNA Gene Analysis}

A fragment of $762 \mathrm{bp}$ was obtained for the $18 \mathrm{~S}$ rRNA gene of C. cuniculus. The BLAST showed highest homology with various C. cuniculus isolated (Acc. Number: MH341587.1; MG516742.1; KT336619.1; KY483978.1, Query Cover: 100\%, Identity: 99.87\%).

An alignment of 798 bp was used for the phylogeny. The result of the Neighbor-Joining analysis based on the $18 S$ rRNA gene is shown in Figure 2.

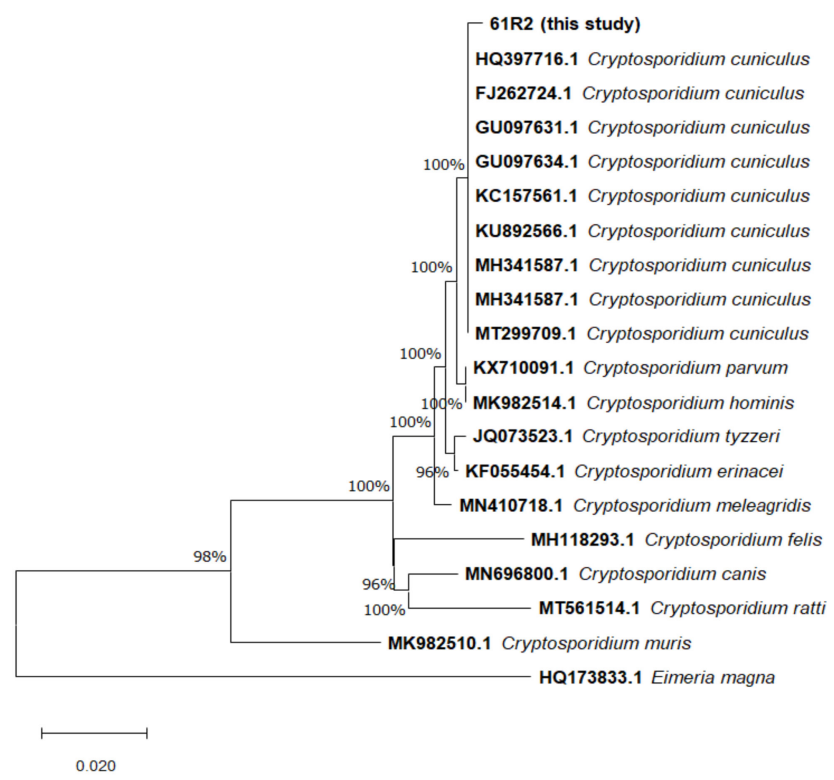

Figure 2. Neighbor-Joining tree of Cryptosporidium spp. based on the $18 S$ rRNA gene sequence. 


\subsection{2. gp60 Analysis}

A fragment of 798 bp was obtained for the gp60 gene of C. cuniculus.

The BLAST analysis showed highest homology with C. cuniculus VbA26subtype (Acc. Number: MT265707.1, Query Cover: 100\%, Identity: 99.87\%), and VbA27 (Acc. Number: KY123920.1, Query Cover: 100\%, Identity: 99.63\%), both isolated from humans in New Zealand.

An alignment of $921 \mathrm{bp}$ was used for the phylogeny. The result of the Neighbor-Joining analysis based on gp60 is shown in Figure 3.

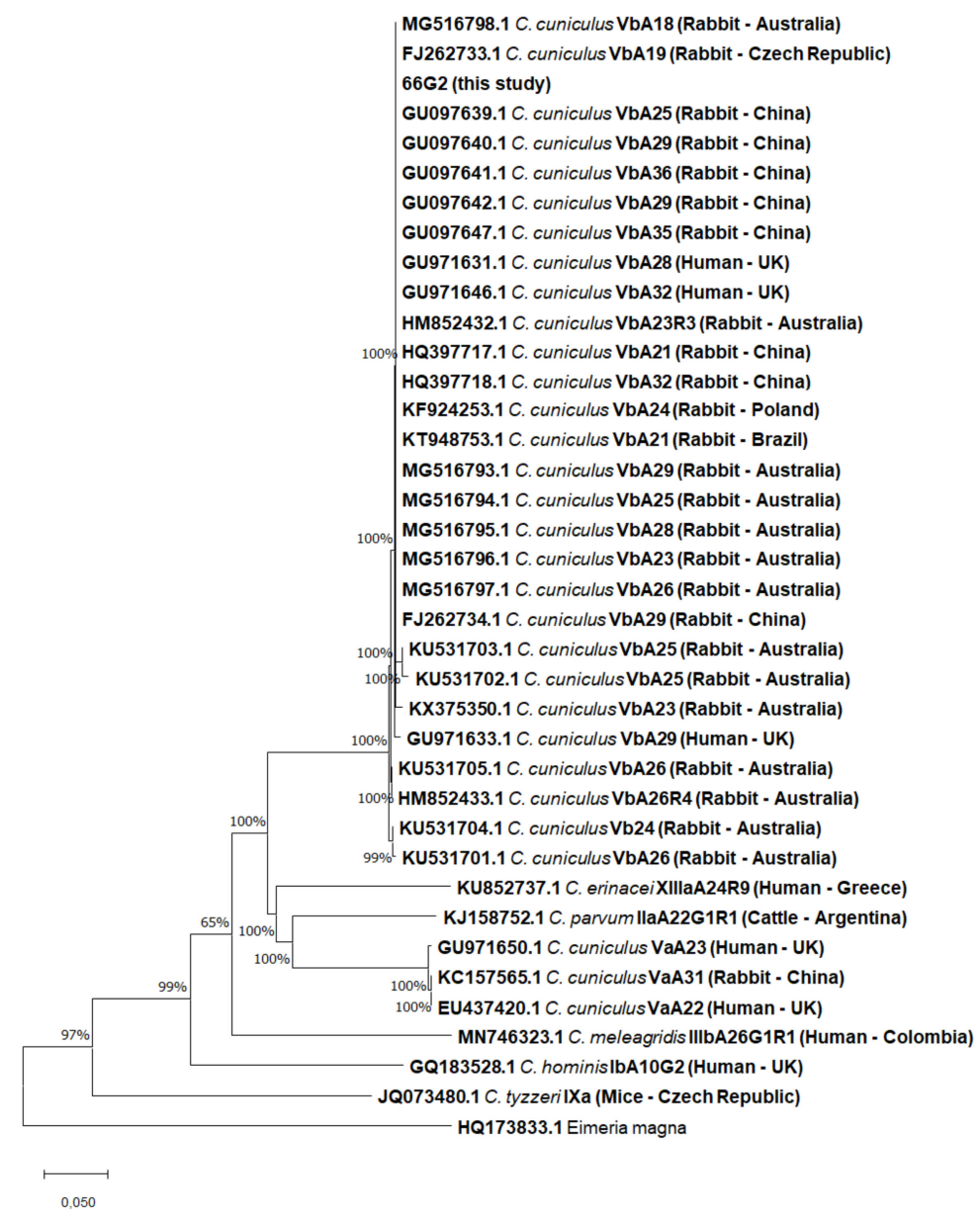

Figure 3. Neighbor-Joining tree of Cryptosporidium spp. genotypes based on gp60. Each sequence is identified by its accession number, species, and subtype, and inserted in brackets are the host and country of origin.

The results of the Neighbor-Joining (Figures 2 and 3) and the maximum-likelihood (Supplementary Material, Figures S1 and S2) analyses based on the 18S rRNA and gp60 genes identified and isolated as C. cuniculus ( $100 \%$ bootstrap) clearly separated to other Cryptosporidium species (Figure 2), belonging to the $\mathrm{Vb}$ family (100\% bootstrap) and differing from the Va family (Figure 3), respectively.

\section{Discussion}

The present study provides data about the occurrence of Cryptosporidium cuniculus in wild rabbits in the Canary Islands. To date, some previous studies carried out in rabbits were based on the detection of Cryptosporidium spp. without reaching the species level due to the techniques employed: faecal examination using light microscopy in pet rabbits in Japan [76], Brazil [77] and Egypt [78]; immunofluorescent microscopy in faecal samples from pet rabbits in the UK [79]; antigen detection by enzyme-linked immunosorbent 
assay (ELISA) in farmed rabbits in Nigeria [80]; and staining methods in rabbits from Spain [81,82], Australia [83], the UK (see [84]), China (see [14]), Iraq [85], and Ecuador [86].

Before the re-description of the C. cuniculus species, other authors cited C. parvum in rabbits, and using light microscopy and indirect immunofluorescence in the UK [87], staining and/or histological techniques in the Czech Republic, Belgium, Hungary, and the USA (see [84]), and staining and molecular methods in China (see [14]) may have led to misdiagnoses.

In the Iberian Peninsula (Spain) from where the Canary rabbit population was introduced, previous studies have already evidenced the presence of Cryptosporidium spp. in faecal samples from rabbits: in farmed rabbits from Toledo [81], farmed rabbits from León, and wild rabbits from Madrid [82], but in these cases the specific diagnosis was not possible. To our knowledge, three publications describing the detection of C. cuniculus in Spain are available, of which two cases were in humans, one autochthonous and a Spanish travel-related case, in addition to a wastewater detection [37,58,59]. However, the molecular detection of C. cuniculus in wild rabbits from Spain had not been reported.

The occurrence of $C$. cuniculus in wild rabbits from Tenerife of $1.0 \%(1 / 100)$ is similar to other studies carried out on wild rabbits from Europe, ranging from $0-0.9 \%$ in Germany $(0 / 232)$ and the UK (1/109). These data differ from those reported in wild rabbits from the UK, 7\% (2/28); Spain, 100\% (7/7) [82], and The Netherlands, 6.5\% (2/31) (see [84]); possibly due to the small size of these studies.

Chalmers et al. 2009 [21] propose the classification of the C. cuniculus subtypes into two families, $\mathrm{Va}$ and $\mathrm{Vb}$, depending on the TCA repetition number in tandem with the microsatellite region of the gp60 gene, and Nolan et al. 2010 [22] recommend the subtype division depends on ACA triplet repetitions in the region immediately following the microsatellite region, specifying it with an R. Following the proposed nomenclature, the novel genotype sequence obtained in this study (Acc. Number: OM249938) should be named VbA26R3.

Other authors cited VbA26subtype detection in wild rabbits from Australia [23,24,26], in Eastern grey kangaroos [24,31], in South Africa river water [42], and humans from the UK [48] and New Zealand [55], thus confirming the zoonotic potential of this subtype.

There are previous studies on molecular epidemiology in wild rabbits, but this was only located in Australia, with prevalence data ranges from 2.18-14.3\%, and with the $\mathrm{Vb}$ family being the only family detected and VbA23subtype being the most prevalent (Table 3), highlighting C. cuniculus as the most prevalent Cryptosporidium species reported in more than 11 host species in wildlife in Australia $[23,24]$. Outside Australia, there is only molecular epidemiology data of farmed rabbits, with prevalence ranging from $2.38-12.73 \%$ (Table 3), and the $\mathrm{Vb}$ family also being the most common (see Supplementary Material, Table S1: Cryptosporidium cuniculus subtypes reported worldwide).

Table 3. Detection of Cryptosporidium cuniculus in rabbits.

\begin{tabular}{|c|c|c|c|c|}
\hline \multicolumn{5}{|c|}{ Farmed Rabbits } \\
\hline Country & Subtype $(n)$ & Period & $\begin{array}{c}\text { Case/Prevalence (\%) } \\
\left(n^{\mathbf{0}} \text { Positive Cases/Total) }\right.\end{array}$ & Reference \\
\hline Czech Republic & VbA19 (1) & - & 2 cases $*$ & {$[19,21]$} \\
\hline China & $\begin{array}{c}\mathrm{VbA} 29(18), \operatorname{VbA} 35(4) \\
\operatorname{VbA} 36(8)\end{array}$ & 2007-2008 & $3.4 \%(37 / 1,081)$ & [13] \\
\hline China & $\operatorname{VbA} 32$ (3), VbA21 (6) & 2008-2010 & $2.38 \%(9 / 378)$ & [14] \\
\hline Poland & VbA24 (-) & 2012 & 300 cases * & [27] \\
\hline Brazil & VbA21 (7) & 2012 & $12.73 \%(7 / 55)$ & [28] \\
\hline
\end{tabular}


Table 3. Cont.

\begin{tabular}{|c|c|c|c|c|}
\hline \multicolumn{5}{|c|}{ Farmed Rabbits } \\
\hline Country & Subtype $(n)$ & Period & $\begin{array}{c}\text { Case/Prevalence (\%) } \\
\text { (n- Positive Cases/Total) }\end{array}$ & Reference \\
\hline China & $\begin{array}{l}\text { VbA28 (2) } \\
\text { VbA29 (16) } \\
\text { VbA32 (3) }\end{array}$ & 2015-2016 & $11.2 \%(24 / 215)$ & [16] \\
\hline China & $\mathrm{VbA} 24(5)$ & 2015-2017 & $3.4 \%(11 / 321)$ & [17] \\
\hline Egypt & $\begin{array}{c}\operatorname{VbA} 19(1) \\
\operatorname{VbA33}(15)\end{array}$ & 2015-2016 & $11.9 \%(28 / 235)$ & [29] \\
\hline China & $\begin{array}{l}\operatorname{VbA} 24(1) \\
\operatorname{VbA} 29(2) \\
\operatorname{VbA31}(2) \\
\operatorname{VbA33}(1)\end{array}$ & - & 6 isolates* & [18] \\
\hline \multicolumn{5}{|c|}{ Wild Rabbits } \\
\hline Country & Subtype (n) & Period & $\begin{array}{c}\text { Case/Prevalence }(\%) \\
\left(n^{\circ} \text { Positive Cases/Total) }\right.\end{array}$ & Reference \\
\hline New Zealand & - & $2000-2003$ & 1 case ${ }^{*}$ & [20] \\
\hline UK & VaA18 (1) & 2008 & 1 case $*$ & [21] \\
\hline Australia & $\begin{array}{l}\operatorname{VbA23R3~(11),~} \\
\operatorname{VbA26R4~(1)~}\end{array}$ & - & $6.8 \%(12 / 176)$ & [22] \\
\hline Australia & $\begin{array}{l}\mathrm{VbA} 22 \mathrm{R} 4(-) \\
\mathrm{VbA} 23 \mathrm{R} 3(-) \\
\mathrm{VbA} 24 \mathrm{R} 3(-) \\
\mathrm{VbA} 25 \mathrm{R} 4(-) \\
\operatorname{VbA26R} 4(-)\end{array}$ & 2009-2011 & $8.4 \%(22 / 263)$ & [23] \\
\hline Australia & $\begin{array}{c}\text { VbA25 (2) } \\
\text { VbA26 (1) } \\
\text { VbA26 novel (3) } \\
\text { VbA24 novel (1) }\end{array}$ & 2011-2015 & $2.18 \%(7 / 321)$ & {$[24]$} \\
\hline Australia & $\mathrm{VbA23}(9)$ & 2013-2015 & $13.2 \%(14 / 106)$ & [25] \\
\hline Australia & $\begin{array}{l}\text { VbA18 (12) } \\
\text { VbA23 (46) } \\
\text { VbA25 (16) } \\
\text { VbA26 (8) } \\
\text { VbA28 (2) } \\
\text { VbA29 (5) }\end{array}$ & 2013-2015 & $14.3 \%(96 / 672)$ & [26] \\
\hline \multicolumn{5}{|c|}{ Others } \\
\hline Country & Subtype (n) & Period & $\begin{array}{c}\text { Case/Prevalence (\%) } \\
\text { (no Positive Cases/Total) }\end{array}$ & Reference \\
\hline $\begin{array}{l}\text { China (unknown } \\
\text { origin) }\end{array}$ & $\operatorname{VbA} 29(1)$ & - & 2 cases * & {$[12,21]$} \\
\hline China (animal house) & VaA31 (3) & - & $1.03 \%(3 / 290)$ & [15] \\
\hline
\end{tabular}

* No prevalence data.

In 2018, Spain was the fourth highest country in the European Union/European Economic Area (EU/EEA) with confirmed cases of cryptosporidiosis [88]. The national cases in 2018 were 1526 (5.22 per 100,000 population) in 11 autonomous communities and the autonomous city of Ceuta (not all of the country is notifying cases). In that year, the Canary Islands had the lowest notification rate of cryptosporidiosis in Spain (0.46 per 100,000 population) [89]. 
Since 2015, cryptosporidiosis has been declared as a notable disease in Spain. From that year, 54 cases have been confirmed in the Canary Islands, and in that period none of them were in Tenerife (Table 4). Considering the previous detection of Cryptosporidium species in Tenerife in humans from 2002-2004 [60], and in wildlife [64,66,67] and wastewater [68,69], possible underdiagnosis may have occurred.

Table 4. Human-confirmed cryptosporidiosis cases in the Canary Islands (2015-2020) [62].

\begin{tabular}{|c|c|c|c|c|}
\hline Year & Cases & Island ( $n$ ) & $\begin{array}{c}\text { Notification Rate } \\
\text { (per 100,000 Population) }\end{array}$ & Reference \\
\hline 2015 & 4 & Gran Canaria (4) & 0.2 & \\
\hline 2016 & 4 & $\begin{array}{c}\text { Gran Canaria }(2) \\
\text { Lanzarote }(2)\end{array}$ & 0.2 & \\
\hline 2017 & 26 & $\begin{array}{c}\text { Gran Canaria (25) } \\
\text { Lanzarote }(1)\end{array}$ & 1.2 & {$[62]$} \\
\hline 2018 & 10 & $\begin{array}{c}\text { Gran Canaria (9) } \\
\text { La Palma (1) }\end{array}$ & 0.5 & \\
\hline 2019 & 7 & Gran Canaria (7) & 0.3 & \\
\hline 2020 & 3 & Gran Canaria (3) & 0.1 & \\
\hline
\end{tabular}

The detection of the zoonotic species C. cuniculus in this study highlights the potential role that wild rabbits can play in the maintenance and transmission of this species. Although the majority of rabbit cases develop asymptomatically, the infection can be associated with different pathologies, which can affect farm productivity and even animal survival, leading to economic losses $[27,81,90]$. On the other hand, while the risk of zoonotic transmission is low, it should not be dismissed since C. cuniculus has been involved in human cases (see Table 1) and outbreaks [21], even becoming the third cause of cryptosporidiosis in the UK [48] and New Zealand [56].

For these reasons, further studies are required to better understand the epidemiology of Cryptosporidium spp. in wild rabbits in the Canary Islands and their possible public health repercussions.

\section{Conclusions}

The present study constitutes the first molecular detection of C. cuniculus in wild rabbits from Tenerife (Canary Islands, Spain), leading to the identification of the VbA26R3 subtype, with potential zoonotic risk. Considering the possible implications to public health of these results, more studies are required in order to evaluate the public health and veterinary risk.

Supplementary Materials: The following supporting information can be downloaded at: https: / / www.mdpi.com/article/10.3390/vetsci9020091/s1: Figure S1: Maximum-Likelihood tree of Cryptosporidium spp. based on the $18 S$ rRNA gene sequence; Figure S2: Maximum-Likelihood tree of Cryptosporidium spp. genotypes based on gp60 sequences; Table S1: Cryptosporidium cuniculus subtypes reported worldwide.

Author Contributions: Conceptualization, P.F.; methodology, E.B.-G., N.M.-C. and K.G.-L.; software, E.B.-G. and P.F.; formal analysis, E.B.-G.; resources, P.F.; data curation, E.B.-G., P.F., N.M.-C. and K.G.-L.; writing —original draft preparation, E.B.-G. and P.F.; writing-review and editing, N.M.-C. and K.G.-L.; supervision, P.F.; project administration, P.F.; funding acquisition, P.F. All authors have read and agreed to the published version of the manuscript.

Funding: This research was funded by Excmo. Cabildo Insular de Tenerife, "Gobierno de Canarias" and FEDER Canarias 2014-2020 grant number ProID2021010013. E.B.-G. was granted a FPI predoctoral scholarship by "Gobierno de Canarias", co-funded by "Fondo Social Europeo" (85\%) and “Consejería de Economía, Industria, Comercio y Conocimiento" (TESIS2021010056). K.G.-L. was granted a scholarship by the Spanish Ministry of Science, Innovation, and Universities and the Universidad de La Laguna (Becas M-ULL, convocatoria 2019). 
Institutional Review Board Statement: Ethical review and approval were waived for this study due to the samples used in this study were donated by hunters that hunted wild rabbits during the legal hunting season period, and no rabbits were sacrificed for this study.

Acknowledgments: We would like to thank the hunters who donated the samples.

Conflicts of Interest: The authors declare no conflict of interest. The funders had no role in the design of the study; in the collection, analyses, or interpretation of data; in the writing of the manuscript, or in the decision to publish the results.

\section{References}

1. Banco de Datos de Biodiversidad de Canarias (EXOS). Available online: https://www.biodiversidadcanarias.es/exos/especie/ V00215 (accessed on 23 December 2021).

2. Ministerio de Agricultura, Pesca y Alimentación (MAPA). Caracterización del Sector Cunícola en España. Año 2020. Available online: https:/ / www.mapa.gob.es/es/ganaderia/temas/produccion-y-mercados-ganaderos/caracterizacioncunicola_rev_t cm30-583128.pdf (accessed on 6 February 2022).

3. Bello-Rodríguez, V.; Mateo, R.G.; Pellissier, L.; Cubas, J.; Cooke, B.; González-Mancebo, J.M. Forecast increase in invasive rabbit spread into ecosystems of an oceanic island (Tenerife) under climate change. Ecol. Appl. 2021, 31, e02206. [CrossRef] [PubMed]

4. Foronda, P.R.; Figueruelo, E.O.; Ortega, A.R.; Abreu, N.A.; Casanova, J.C. Parasites (viruses, coccidia and helminths) of the wild rabbit (Oryctolagus cuniculus) introduced to Canary Islands from Iberian Peninsula. Acta Parasitol. 2005, 50, 80-84.

5. $\quad$ Prediger, J.; Ježková, J.; Holubová, N.; Sak, B.; Konečný, R.; Rost, M.; McEvoy, J.; Rajský, D.; Kváč, M. Cryptosporidium sciurinum n. sp. (Apicomplexa: Cryptosporidiidae) in Eurasian Red Squirrels (Sciurus vulgaris). Microorganisms 2021, 9, 2050. [CrossRef] [PubMed]

6. O'Donoghue, P.J. Cryptosporidium infections in man, animals, birds and fish. Aust. Vet. J. 1985, 62, 253-258. [CrossRef] [PubMed]

7. Fayer, R.; Morgan, U.; Upton, S.J. Epidemiology of Cryptosporidium: Transmission, detection and identification. Int. J. Parasitol. 2000, 30, 1305-1322. [CrossRef]

8. Daraei, H.; Conti, G.O.; Sahlabadi, F.; Thai, V.N.; Gholipour, S.; Turki, H.; Fakhri, Y.; Ferrante, M.; Moradi, A.; Khaneghah, A.M. Prevalence of Cryptosporidium spp. in water: A global systematic review and meta-analysis. Environ. Sci. Pollut. Res. Int. 2020, 28, 9498-9507. [CrossRef]

9. Tyzzer, E.E. Cryptosporidium parvum (sp. nov.) a coccidium found in the small intestine of the common mouse. Arch. Protistenkd. $1912,26,394-412$.

10. Inman, L.R.; Takeuchi, A. Spontaneous cryptosporidiosis in an adult female rabbit. Vet. Pathol. 1979, 16, 89-95. [CrossRef]

11. Robinson, G.; Wright, S.; Elwin, K.; Hadfield, S.J.; Katzer, F.; Bartley, P.M.; Hunter, P.R.; Nath, M.; Innes, E.A.; Chalmers, R.M. Re-description of Cryptosporidium cuniculus Inman and Takeuchi, 1979 (Apicomplexa: Cryptosporidiidae): Morphology, biology and phylogeny. Int. J. Parasitol. 2010, 40, 1539-1548. [CrossRef]

12. Xiao, L.; Sulaiman, I.M.; Ryan, U.M.; Zhou, L.; Atwill, E.R.; Tischler, M.L.; Zhang, X.; Fayer, R.; Lal, A.A. Host adaptation and host-parasite co-evolution in Cryptosporidium: Implications for taxonomy and public health. Int. J. Parasitol. 2002, 32, 1773-1785. [CrossRef]

13. Shi, K.; Jian, F.; Lv, C.; Ning, C.; Zhang, L.; Ren, X.; Dearen, T.K.; Li, N.; Qi, M.; Xiao, L. Prevalence, Genetic Characteristics, and Zoonotic Potential of Cryptosporidium Species Causing Infections in Farm Rabbits in China. J. Clin. Microbiol. 2010, 48, 3263-3266. [CrossRef]

14. Zhang, W.; Shen, Y.; Wang, R.; Liu, A.; Ling, H.; Li, Y.; Cao, J.; Zhang, X.; Shu, J.; Zhang, L. Cryptosporidium cuniculus and Giardia duodenalis in rabbits: Genetic diversity and possible zoonotic transmission. PLoS ONE 2012, 7, e31262. [CrossRef]

15. Liu, X.; Zhou, X.; Zhong, Z.; Chen, W.; Deng, J.; Niu, L.; Wang, Q.; Peng, G. New subtype of Cryptosporidium cuniculus isolated from rabbits by sequencing the Gp60 gene. J. Parasitol. 2014, 100, 532-536. [CrossRef]

16. Yang, Z.; Zhao, W.; Shen, Y.; Zhang, W.; Shi, Y.; Ren, G.; Yang, D.; Ling, H.; Yang, F.; Liu, A.; et al. Subtyping of Cryptosporidium cuniculus and genotyping of Enterocytozoon bieneusi in rabbits in two farms in Heilongjiang Province, China. Parasite 2016, 23, 52. [CrossRef] [PubMed]

17. Zhang, X.; Qi, M.; Jing, B.; Yu, F.; Wu, Y.; Chang, Y.; Zhao, A.; Wei, Z.; Dong, H.; Zhang, L. Molecular Characterization of Cryptosporidium spp., Giardia duodenalis and Enterocytozoon bieneusi in Rabbits in Xinjiang, China. J. Eukaryot. Microbiol. 2018, 65, 854-859. [CrossRef] [PubMed]

18. Lu, C.; Liu, X.; Liu, J.; Tang, X.; Zhu, G.; Striepen, B.; Suo, X. Immunocompetent rabbits infected with Cryptosporidium cuniculus as an animal model for anti-cryptosporidial drug testing. Int. J. Parasitol. 2021. [CrossRef] [PubMed]

19. Ryan, U.; Xiao, L.; Carolyn, R.; Zhou, L.; Lal, A.A.; Pavlasek, I. Identification of novel Cryptosporidium genotypes from the Czech Republic. Appl. Environ. Microbiol. 2003, 69, 4302-4307. [CrossRef]

20. Learmonth, J.; Ionas, G.; Ebbett, K.A.; Kwan, E.S. Genetic characterization and transmission cycles of Cryptosporidium species isolated from humans in New Zealand. Appl. Environ. Microbiol. 2004, 70, 973-978. [CrossRef]

21. Chalmers, R.M.; Robinson, G.; Elwin, K.; Hadfield, S.J.; Xiao, L.; Ryan, U.M.; Modha, D.; Mallaghan, C. Cryptosporidium sp. rabbit genotype, a newly identified human pathogen. Emerg. Infect. Dis. 2009, 15, 829-830. [CrossRef] 
22. Nolan, M.J.; Jex, A.R.; Haydon, S.R.; Stevens, M.A.; Gasser, R.B. Molecular detection of Cryptosporidium cuniculus in rabbits in Australia. Infect. Genet. Evol. 2010, 10, 1179-1187. [CrossRef]

23. Nolan, M.J.; Jex, A.R.; Koehler, A.V.; Haydon, S.R.; Stevens, M.A.; Gasser, R.B. Molecular-based investigation of Cryptosporidium and Giardia from animals in water catchments in southeastern Australia. Water Res. 2013, 47, 1726-1740. [CrossRef] [PubMed]

24. Koehler, A.V.; Haydon, S.R.; Jex, A.R.; Gasser, R.B. Cryptosporidium and Giardia taxa in faecal samples from animals in catchments supplying the city of Melbourne with drinking water (2011 to 2015). Parasit. Vectors 2016, 9, 315. [CrossRef] [PubMed]

25. Zahedi, A.; Monis, P.; Aucote, S.; King, B.; Paparini, A.; Jian, F.; Yang, R.; Oskam, C.; Ball, A.; Robertson, I.; et al. Zoonotic Cryptosporidium Species in Animals Inhabiting Sydney Water Catchments. PLoS ONE 2016, 11, e0168169. [CrossRef] [PubMed]

26. Zahedi, A.; Monis, P.; Gofton, A.W.; Oskam, C.L.; Ball, A.; Bath, A.; Bartkow, M.; Robertson, I.; Ryan, U. Cryptosporidium species and subtypes in animals inhabiting drinking water catchments in three states across Australia. Water Res. 2018, 134, 327-340. [CrossRef] [PubMed]

27. Kaupke, A.; Kwit, E.; Chalmers, R.M.; Michalski, M.M.; Rzeżutka, A. An outbreak of massive mortality among farm rabbits associated with Cryptosporidium infection. Res. Vet. Sci. 2014, 97, 85-87. [CrossRef] [PubMed]

28. Heker, M.M.; Nakamura, A.A.; Meireles, M.V. Molecular characterization of Cryptosporidium spp. in Brazilian rabbit farms. Arq. Bras. Med. Vet. Zootec. 2016, 68, 977-982. [CrossRef]

29. Naguib, D.; Roellig, D.M.; Arafat, N.; Xiao, L. Genetic Characterization of Cryptosporidium cuniculus from Rabbits in Egypt. Pathogens 2021, 10, 775. [CrossRef]

30. Ayinmode, A.B.; Agbajelola, V.I. Molecular identification of Cryptosporidium parvum in rabbits (Oryctolagus cuniculus) in Nigeria. Ann. Parasitol. 2019, 65, 237-243.

31. Koehler, A.V.; Whipp, M.J.; Haydon, S.R.; Gasser, R.B. Cryptosporidium cuniculus-new records in human and kangaroo in Australia Parasit. Vectors 2014, 7, 492. [CrossRef]

32. Koehler, A.V.; Rashid, M.H.; Zhang, Y.; Vaughan, J.L.; Gasser, R.B.; Jabbar, A. First cross-sectional, molecular epidemiological survey of Cryptosporidium, Giardia and Enterocytozoon in alpaca (Vicugna pacos) in Australia. Parasit. Vectors 2018, 11, 498. [CrossRef]

33. Puleston, R.L.; Mallaghan, C.M.; Modha, D.E.; Hunter, P.R.; Nguyen-Van-Tam, J.S.; Regan, C.M.; Nichols, G.L.; Chalmers, R.M. The first recorded outbreak of cryptosporidiosis due to Cryptosporidium cuniculus (formerly rabbit genotype), following a water quality incident. J. Water Health 2014, 12, 41-50. [CrossRef] [PubMed]

34. Li, N.; Xiao, L.; Wang, L.; Zhao, S.; Zhao, X.; Duan, L.; Guo, M.; Liu, L.; Feng, Y. Molecular surveillance of Cryptosporidium spp., Giardia duodenalis, and Enterocytozoon bieneusi by genotyping and subtyping parasites in wastewater. PLoS Negl. Trop. Dis. 2012, 6, e1809. [CrossRef] [PubMed]

35. Xiao, D.; Lyu, Z.; Chen, S.; Huo, Y.; Fan, W.; Huo, M. Tracking Cryptosporidium in urban wastewater treatment plants in a cold region: Occurrence, species and infectivity. Front. Environ. Sci. Eng. 2022, 16, 1-14. [CrossRef]

36. Ulloa-Stanojlović, F.M.; Aguiar, B.; Jara, L.M.; Zanoli-Sato, M.I.; Arzola-Guerrero, J.; Hachich, E.; Rogério-Matté, G.; Dropa, M.; Matté, M.H.; de Araújo, R.S. Occurrence of Giardia intestinalis and Cryptosporidium sp. in wastewater samples from São Paulo State, Brazil, and Lima, Peru. Environ. Sci. Pollut. Res. Int. 2016, 23, 22197-22205. [CrossRef]

37. Ramo, A.; del Cacho, E.; Sánchez-Acedo, C.; Quílez, J. Occurrence and genetic diversity of Cryptosporidium and Giardia in urban wastewater treatment plants in north-eastern Spain. Sci. Total Environ. 2017, 598, 628-638. [CrossRef]

38. Zahedi, A.; Gofton, A.W.; Greay, T.; Monis, P.; Oskam, C.; Ball, A.; Bath, A.; Watkinson, A.; Robertson, I.; Ryan, U. Profiling the diversity of Cryptosporidium species and genotypes in wastewater treatment plants in Australia using next generation sequencing Sci. Total Environ. 2018, 644, 635-648. [CrossRef] [PubMed]

39. Zahedi, A.; Greay, T.L.; Paparini, A.; Linge, K.L.; Joll, C.A.; Ryan, U.M. Identification of eukaryotic microorganisms with 18S rRNA next-generation sequencing in wastewater treatment plants, with a more targeted NGS approach required for Cryptosporidium detection. Water Res. 2019, 158, 301-312. [CrossRef]

40. Hu, Y.; Feng, Y.; Huang, C.; Xiao, L. Occurrence, source, and human infection potential of Cryptosporidium and Enterocytozoon bieneusi in drinking source water in Shanghai, China, during a pig carcass disposal incident. Environ. Sci. Technol. 2014, 48, 14219-14227. [CrossRef]

41. Swaffer, B.; Vial, H.M.; King, B.J.; Daly, R.; Frizenschaf, J.; Monis, P.T. Investigation source water Cryptosporidium concentration, species and infectivity rates during rainfall-runoff in a multi-use catchment. Water Res. 2014, 67, 310-320. [CrossRef]

42. Mphephu, M.G.; Ekwanzala, M.D.; Momba, M.N.B. Cryptosporidium species and subtypes in river water and riverbed sediment using next-generation sequencing. Int. J. Parasitol. 2021, 51, 339-351. [CrossRef]

43. Swaffer, B.; Abbott, H.; King, B.; van der Linden, L.; Monis, P. Understanding human infectious Cryptosporidium risk in drinking water supply catchments. Water Res. 2018, 138, 282-292. [CrossRef] [PubMed]

44. Zahedi, A.; Ryan, U.; Rawlings, V.; Greay, T.; Hancock, S.; Bruce, M.; Jacobson, C. Cryptosporidium and Giardia in dam water on sheep farms-An important source of transmission? Vet. Parasitol. 2020, 288, 109281. [CrossRef] [PubMed]

45. Cacciò, S.M.; Chalmers, R.M. Human cryptosporidiosis in Europe. Clin. Microbiol. Infect. 2016, 22, 471-480. [CrossRef] [PubMed]

46. Cieloszyk, J.; Goñi, P.; García, A.; Remacha, M.A.; Sánchez, E.; Clavel, A. Two cases of zoonotic cryptosporidiosis in Spain by the unusual species Cryptosporidium ubiquitum and Cryptosporidium felis. Enferm. Infecc. Microbiol. Clin. 2012, 30, 549-551. [CrossRef] [PubMed] 
47. Robinson, G.; Elwin, K.; Chalmers, R.M. Unusual Cryptosporidium Genotypes in Human Cases of Diarrhea. Emerg. Infect. Dis. 2008, 14, 1800-1802. [CrossRef] [PubMed]

48. Chalmers, R.M.; Elwin, K.; Hadfield, S.J.; Robinson, G. Sporadic Human Cryptosporidiosis Caused by Cryptosporidium cuniculus, United Kingdom, 2007-2008. Emerg. Infect. Dis. 2011, 17, 536-538. [CrossRef] [PubMed]

49. McKerr, C.; Chalmers, R.M.; Elwin, K.; Ayres, H.; Vivancos, R.; O’Brien, S.J.; Christley, R.M. Cross-sectional household transmission study of Cryptosporidium shows tht C. hominis infections are a key risk factor for spread. BMC Infect. Dis. 2022, 22, 114. [CrossRef]

50. ANOFEL Cryptosporidium National Network. Laboratory based surveillance for Cryptosporidium in France, 2006-2009. Euro. Surveill. 2010, 15, 19642.

51. Costa, D.; Razakandrainibe, R.; Sautour, M.; Valot, S.; Basmaciyan, L.; Gargala, G.; Lemeteil, D.; French National Network on Surveillance of Human Cryptosporidiosis. Human Cryptosporidiosis in immunodeficient patients in France (2015-2017). Exp. Parasitol. 2018, 192, 108-112. [CrossRef]

52. Costa, D.; Razakandrainibe, R.; Valor, S.; Vannier, M.; Sautour, M.; Basmaciyan, L.; Gargala, G.; Viller, V.; Lemeteil, D.; Ballet, J.J.; et al. Epidemiology of Cryptosporidiosis in France from 2017 to 2019. Microorganisms 2020, 8, 1358. [CrossRef]

53. Molloy, S.F.; Smith, H.V.; Kirwan, P.; Nichols, R.A.B.; Asaolu, S.O.; Connelly, L.; Holland, C.V. Identification of a high diversity of Cryptosporidium species genotypes and subtypes in a pediatric population in Nigeria. Am. J. Trop. Med. Hyg. 2010, 82, 608-613. [CrossRef] [PubMed]

54. García-R, J.C.; French, N.; Pita, A.; Velathanthiri, N.; Shrestha, R.; Hayman, D. Local and global genetic diversity of protozoan parasites: Spatial distribution of Cryptosporidium and Giardia genotypes. PLoS Negl. Trop. Dis. 2017, 11, e0005736. [CrossRef] [PubMed]

55. García-R, J.C.; Pita, A.B.; Velathanthiri, N.; French, N.P.; Hayman, D.T.S. Species and genotypes causing human cryptosporidiosis in New Zealand. Parasitol. Res. 2020, 119, 2317-2326. [CrossRef]

56. Knox, M.A.; García-R, J.C.; Ogbuigwe, P.; Pita, A.; Velathanthiri, N.; Hayman, D.T.S. Absence of Cryptosporidium hominis and dominance of zoonotic Cryptosporidium species in patients after Covid-19 restrictions in Auckland, New Zealand. Parasitology 2021, 148, 1288-1292. [CrossRef] [PubMed]

57. Guy, R.A.; Yanta, C.A.; Muchaal, P.K.; Rankin, M.A.; Thivierge, K.; Lau, R.; Boggild, A.K. Molecular characterization of Cryptosporidium isolates from humans in Ontario, Canada. Parasit. Vectors 2021, 14, 69. [CrossRef]

58. Lebbad, M.; Winiecka-Krusnell, J.; Stensvold, C.R.; Beser, J. High Diversity of Cryptosporidium Species and Subtypes Identified in Cryptosporidiosis Acquired in Sweden and Abroad. Pathogens 2021, 10, 523. [CrossRef]

59. Martínez-Ruiz, R.; de Lucio, A.; Fuentes, I.; Carmena, D. Autochthonous Cryptosporidium cuniculus infection in Spain: First report in a symptomatic paediatric patient from Madrid. Enferm. Infecc. Microbiol. Clin. 2016, 34, 532-534. [CrossRef]

60. Abreu-Acosta, N.; Quispe, M.A.; Foronda-Rodríguez, P.; Alcoba-Florez, J.; Lorenzo-Morales, J.; Ortega-Rivas, A.; Valladares, B. Cryptosporidium in patients with diarrhea, on Tenerife, Canary Islands, Spain. Ann. Trop. Med. Parasitol. 2007, 101, 539-545. [CrossRef]

61. Novo-Veleiro, I.; Martín-Sánchez, A.M.; Elcuaz-Romano, R.; Afonso, O.; García-Bardeci, D.; Bordes-Benítez, A.; CarranzaRodríguez, C.; Hernández-Cabrera, M.; Alvela-Suárez, M.L.; Pérez-Arellano, J.L.; et al. Parasitosis en Gran Canaria (España) Estudio Prospectivo Multicéntrico Durante Un Año. Rev. Ibero-Latinoam. Parasitol. 2012, 71, 34-41.

62. Sistema EDO de la Red Canaria de Vigilancia Epidemiológica. Available online: https://www3.gobiernodecanarias.org/sanida d/scs / contenidoGenerico.jsp?idDocument=72483736-0d7a-11de-9de1-998efb13096d\&idCarpeta=0f67aaf7-9d88-11e0-b0dc-e5 5 e53ccc42c (accessed on 22 December 2021).

63. Rodríguez, F.; Orós, J.; Rodríguez, J.L.; González, J.; Castro, P.; Fernández, A. Intestinal cryptosporidiosis in pigeons (Columba livia). Avian Dis. 1997, 41, 748-750. [CrossRef]

64. Abreu-Acosta, N.; Foronda-Rodríguez, P.; López, M.; Valladares, B. Occurrence of Cryptosporidium hominis in pigeons (Columba livia). Acta Parasitol. 2009, 54, 1-5. [CrossRef]

65. Feliu, C.; López, M.; Gómez, M.S.; Torres, J.; Sánchez, S.; Miquel, J.; Abreu-Acosta, N.; Segovia, J.M.; Martín-Alonso, A.; Montoliu, I.; et al. Parasite fauna of rodents (Murinae) from El Hierro (Canary Islands, Spain): A multidisciplinary approach. Acta Parasitol. 2012, 57, 171-178. [CrossRef] [PubMed]

66. García-Livia, K.; Martín-Alonso, A.; Foronda, P. Diversity of Cryptosporidium spp. in wild rodents from the Canary Islands, Spain Parasit. Vectors 2020, 13, 445. [CrossRef] [PubMed]

67. Izquierdo-Rodríguez, E.; Martín-Carrillo, N.; Valladares, B.; Foronda, P. Study of Zoonotic Enteric Pathogens of Atelerix algirus in Tenerife, Canary Islands, Spain. Front. Vet. Sci 2020, 7, 579602. [CrossRef]

68. Abreu-Acosta, N.; Martín-Delgado, M.; Ortega-Rivas, A.; del Castillo-Remiro, A.; Aguiar-González, E.; Valladares, B. Giardia lamblia and Cryptosporidium spp. presence in treated wastewater reutilised for irrigation in Tenerife Island, Spain. Long-distance transport effects in the reutilised water quality. Rev. Salud Ambient. 2002, 2, 2-7.

69. Abreu-Acosta, N.; Vera, L. Occurrence and removal of parasites, enteric bacteria and faecal contamination indicators in wastewater natural reclamation systems in Tenerife-Canary Islands, Spain. Ecol. Eng. 2011, 37, 496-503. [CrossRef]

70. Manore, A.J.W.; Harper, S.L.; Aguilar, B.; Weese, J.S.; Shapiro, K. Comparison of freeze-thaw cycles for nucleic acid extraction and molecular detection of Cryptosporidium parvum and Toxoplasma gondii oocysts in environmental matrices. J. Microbiol. Methods 2019, 156, 1-4. [CrossRef] 
71. Zhao, G.H.; Ren, W.X.; Gao, M.; Bian, Q.Q.; Hu, B.; Cong, M.M.; Lin, Q.; Wang, R.J.; Qi, M.; Qi, M.Z.; et al. Genotyping Cryptosporidium andersoni in cattle in Shaanxi Province, Northwestern China. PLoS ONE 2013, 8, e60112. [CrossRef]

72. Alves, M.; Xiao, L.; Sulaiman, I.; Lal, A.A.; Matos, O.; Antunes, F. Subgenotype analysis of Cryptosporidium isolates from humans, cattle, and zoo rumiants in Portugal. J. Clin. Microbiol. 2003, 41, 2744-2747. [CrossRef]

73. Kumar, S.; Stecher, G.; Li, M.; Knyaz, C.; Tamura, K. MEGA X: Molecular evolutionary genetics analysis across computing platforms. Mol. Biol. Evol. 2018, 35, 1547-1549. [CrossRef]

74. Saitou, N.; Nei, M. The neighbor-joining method: A new method for reconstructing phylogenetic trees. Mol. Biol. Evol. 1987, 4, 406-425. [PubMed]

75. Tamura, K.; Nei, M. Estimation of the number of nucleotide substitutions in the control region of mitochondrial DNA in humans and chimpanzees. Mol. Biol. Evol. 1993, 10, 512-526. [PubMed]

76. Shiibashi, T.; Imai, T.; Sato, Y.; Abe, N.; Yukawa, M.; Nogami, S. Cryptosporidium infection in juvenile pet rabbits. J. Vet. Med. Sci. 2006, 68, 281-282. [CrossRef]

77. Da Silva, A.S.; Ceolin, L.V.; Monteiro, S.G. Endoparasitoses de coelhos criados em diferentes sistemas de manejo. Rev. FZVA 2006, 13, 127-136.

78. Elshahawy, I.; Elgoniemy, A. An Epidemiological Study on Endoparasites of Domestic Rabbits (Oryctolagus cuniculus) in Egypt with Special Reference to Their Health Impact. Sains Malays. 2018, 47, 9-18. [CrossRef]

79. Smith, R.P.; Chalmers, R.M.; Elwin, K.; Clifton-Hadley, F.A.; Mueller-Doblies, D.; Watkins, J.; Paiba, G.A.; Giles, M. Investigation of the Role of Companion Animals in the Zoonotic Transmission of Cryptosporidiosis. Zoonoses Public Health 2009, $56,24-33$. [CrossRef] [PubMed]

80. Akinkuotu, O.A.; Akinkuotu, A.C.; Oseni, O.T. Prevalence of Cryptosporidium Infection in a Rabbitory in Abeokuta, Nigeria. Nig. Vet. J. 2016, 37, 243-246.

81. Respaldiza-Cardeñosa, E.; Simón-Palacios, M.C.; Respaldiza-Fernández, E. Estudio de un Foco de Criptosporidiosis en Conejo. XIV Symposium de Cunicultura. Manresa. Boletín De Cunicult. 1989, 46, 47-49.

82. Del Águila, C.; Izquierdo, F.; Navajas, R.; Pieniazek, N.J.; Miró, G.; Alonso, A.I.; Da Silva, A.J.; Fenoy, S. Enterocytozoon bieneusi in animals: Rabbits and dogs as new hosts. J. Eukaryot. Microbiol. 1999, 46, 8-9.

83. Cox, P.; Griffith, M.; Angles, M.; Deere, D.; Ferguson, C. Concentrations of pathogens and indicators in animal feces in the Sydney watershed. Appl. Environ. Microbiol. 2005, 71, 5929-5934. [CrossRef]

84. Robinson, G.; Chalmers, R.M. The European rabbit (Oryctolagus cuniculus), a source of zoonotic cryptosporidiosis. Zoonoses Public Health 2010, 57, 13. [CrossRef] [PubMed]

85. Marhoon, I.A.; Mattar, K.T.; Mohammad, F.I. Parasitic Infection in Wild Rabbits Oryctolagus cuniculus. Eurasian. J. Anal. Chem. 2018, 13, 55. [CrossRef]

86. González-Ramírez, L.C.; Vázquez, C.J.; Chimbaina, M.B.; Djabayan-Djibeyan, P.; Prato-Moreno, J.G.; Trelis, M.; Fuentes, M.V. Ocurrence of enteroparasites with zoonotic potential in animals of the rural area of San Andres, Chimborazo, Ecuador. Vet. Parasitol. Reg. Stud. 2021, 26, 100630. [CrossRef] [PubMed]

87. Sturdee, A.P.; Chalmers, R.M.; Bull, S.A. Detection of Cryptosporidium oocysts in wild mammals of mainland Britain. Vet. Parasitol. 1999, 80, 273-280. [CrossRef]

88. European Centre for Disease Prevention and Control (ECDC). Available online: http://atlas.ecdc.europa.eu/public/index.aspx ?Dataset $=27 \&$ HealthTopic $=15$ (accessed on 22 December 2012).

89. Instituto de Salud Carlos III (ISCIII). Available online: https://www.isciii.es/QueHacemos/Servicios/VigilanciaSaludPublicaR ENAVE/EnfermedadesTransmisibles/Documents/INFORMES/INFORMES\%20RENAVE/ultimo\%20informe.pdf (accessed on 22 December 2012).

90. Robertson, L.J.; Björkman, C.; Axén, C.; Fayer, R. Cryptosporidiosis in Farmed Animals. In Cryptosporidium: Parasite and Disease; Cacciò, S.M., Widmer, G., Eds.; Springer: Berlin/Heidelberg, Germany, 2014; pp. 149-236. 